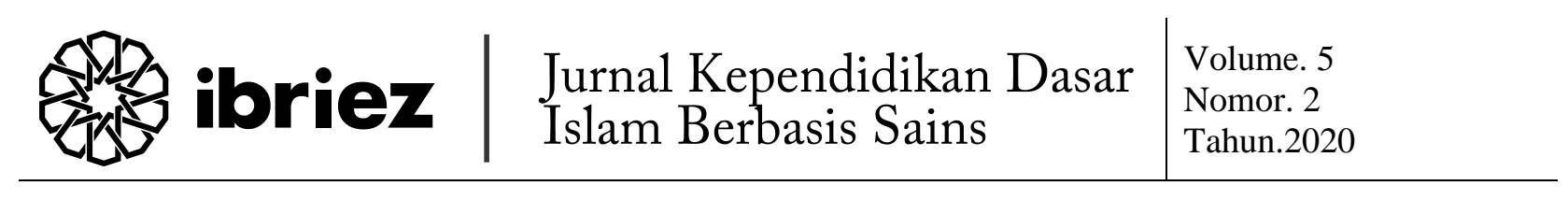

\title{
Teaching and Learning in Industrial Era 4.0
}

\author{
Sri Idayatun \\ Madrasah Aliyah Negeri (MAN) 1 Kudus \\ Surel : idayatunsri@gmail.com
}

\begin{abstract}
In the Industrial Revolution 4.0, education is a big challenge this century. If we don't change the way we teach, the next 30 years we will experience great difficulties. Education and learning that are conditional on the content of knowledge, leaving aside the content of attitudes and skills as being implemented, will result in students who are unable to compete with machines. The dominance of knowledge in education and learning must be changed so that in the future children will be able to surpass machine intelligence. The role of teacher is not only as an educator, but also as a facilitator, and potential student digger. Professional teachers are needed who are able to take advantage of the information technology era. Teachers must be able to use it to improve the quality of teaching. This is in order to prepare superior human resources with global competence or $21^{\text {st }}$ century skills.
\end{abstract}

Keywords: industry, teachers, machine, intelligence, global, competence

\section{Preface}

The teacher holds the main player in carrying out the learning process. A perfect curriculum, even complete learning facilities will not have a significant influence on the success of learning without the support of teachers' readiness to face every challenge. For this reason, the government has made appropriate efforts to pay special attention to improving the professionalism of teachers in the past

\footnotetext{
${ }^{1}$ Afrianto Afrianto, "Being a Professional Teacher in the Era of Industrial Revolution 4.0: Opportunities, Challenges and Strategies for Innovative Classroom Practices," English
}

decade, including the issuance of teacher and lecturer law 14/2015. ${ }^{1}$

In the teacher and lecturer law, the context of teacher professionalism in Indonesia is divided into 4 main competencies, namely: professional competence, pedagogical competence, social competence, and personal competence. The government is paying special attention to efforts to prepare professional teachers in all four aspects.

Language Teaching and Research 2, no. 1

(December 22, 2018),

http://ejournal.unp.ac.id/index.php/eltar/article/ view/102675. 
The era of the industrial revolution 4.0 has demanded that teachers change the learning process. ${ }^{2}$ Changes made are not just about how to teach, but far more essential, changes in the way of viewing the concept of learning itself. Learning must at least be able to prepare students to deal with three things: a) prepare children to be able to work for which there is currently no work; b) prepare children to be able to solve problems for which problems have not yet arisen, and c) prepare children to be able to use technology where technology has not yet been discovered. What a homework that is not easy for the world of learning. To be able to face these challenges, an important requirement that must be met is how to prepare qualified teacher qualifications and competencies.

This paper will focus on discussing the changes that are happening now in the industrial revolution 4.0 or disruptive era and how this era has an influence on the learning process. This paper will specifically address three important questions, namely: a) what and how was the era of the industrial revolution 4.0 ? b) What are the challenges and opportunities brought by the era of the industrial revolution 4.0 to the learning process? c) What must teachers do about the challenges and opportunities brought about by the industrial revolution era 4.0 to make the learning process in the classroom better?

\footnotetext{
${ }^{2}$ A. H. Johnstone, "The Development of Chemistry

Teaching: A Changing Response to Changing Demand," Journal of Chemical Education 70, no. 9 (1993): 701-5, https://doi.org/10.1021/ed070p701.
}

\section{Era Industry 4.0}

The characteristics of the industrial revolution era 4.0 or the era of disruption can be explained through (VUCA), namely changes that are massive, fast, with patterns that are difficult to predict (Volatility), changes that quickly lead to uncertainty (Uncertainty), the complexity of the relationship between the factors causing change (Complexity), lack of clarity in the direction of change that causes ambiguity (Ambiguity). ${ }^{3}$ In this era information technology has become the basis or basis in human life, including in the field of education in Indonesia. In the Industrial Revolution Era 4.0 several things happened to become limitless through computing technology and unlimited data (big data), this happened because it was influenced by the development of the internet and digital technology as a massive backbone of the movement and connectivity of humans and machines. This era will also disrupt various human activities

The emergence of a steam engine in the $18^{\text {th }}$ century has succeeded in accelerating the economy dramatically which in the period of two centuries has been able to increase the per capita income of countries in the world to sixfold. The second industrial revolution is known

\footnotetext{
${ }^{3}$ Valeria E. Guzmán et al., "Characteristics and Skills of Leadership in the Context of Industry 4.0," in Procedia Manufacturing, vol. 43 (Elsevier B.V., 2020), 543-50, https://doi.org/10.1016/j.promfg.2020.02.167.
} 


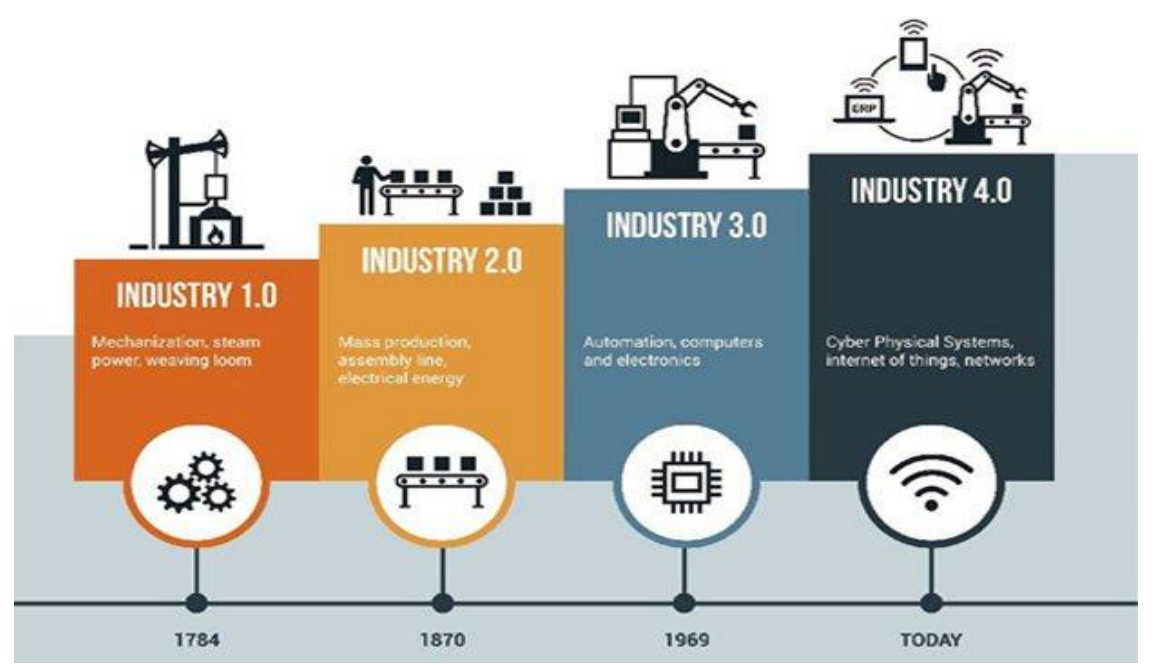

Figure 1. Development of the Industrial Revolution 4.0

as the technological revolution. ${ }^{4}$ This revolution was marked by the use and production of iron and steel on a large scale, the widespread use of steam power, telegraph machines. In addition, petroleum was discovered and used extensively and the initial period of electricity was used. In the third industrial revolution, the manufacturing industry has turned into a digital business. Digital technology has dominated the media and retail industries. The third industrial revolution changed the pattern of relations and communication in contemporary society. This revolution has shortened distance and time, this revolution put forward the real time side. ${ }^{5}$ Major changes occurred in the industrial sector in the era of the fourth industrial revolution, we can see today where information and communication technology is fully utilized in almost all

${ }^{4}$ JA Goldstone, "Efflorescences and Economic Growth in World History: Rethinking the" Rise of the West" and the Industrial Revolution," Journal of World History 3, no. 2 (2002): 323-389.

${ }^{5}$ A Sreberny and A Mohammadi, Small Media, Big Revolution: Communication, Culture, and the lines of human life. In this era, almost all business models underwent major changes.

The name of industry 4.0 originated from a project initiated by the German government to promote computerized manufacturing. Germany is the first country to make a roadmap (grand design) about the implementation of the digital economy. The era of the industrial revolution is also known as the digital revolution and the era of disruption. The term disruption can be interpreted literally "uprooted from its roots". Disruption is also interpreted as innovation. From the terms above, disruption can be interpreted as a fundamental or fundamental change in innovation. In this era of disruption, fundamental changes occur because of massive changes in technology in every aspect of people's lives. ${ }^{6}$

Iranian Revolution (Minnesota: University of Minnesota, 1994).

${ }^{6}$ A Savitri, Revolusi Industri 4.0: Mengubah Tantangan Menjadi Peluang Di Era Disrupsi 4.0 (Yogyakarta: Genesis, 2019), 7-26. 
The industrial revolution began with a) the Industrial Revolution 1.0 occurred in the 18th century through the invention of the steam engine, thereby enabling goods to be mass produced, b) the Industrial Revolution 2.0 occurred in the 19-20th century through the use of electricity which made production costs cheap, c) Industrial Revolution 3.0 occurred around the 1970s through the use of computerization, and d) Industrial Revolution 4.0 itself occurred around the year 2010 through engineering intelligence (artificial intelligence) and the internet of things as the backbone of the movement and connectivity of humans and machines. ${ }^{7}$

\section{Industrial Era 4.0 and Learning Process}

The development of learning process in the classroom is inseparable from the development of the industrial revolution era 4.0 , because indirectly changes in the economic order also change the order of learning process in a country. ${ }^{8}$ Information and technology affect learning activities very massively. New information and knowledge spread easily and accessible to anyone who needs it. Learning experiences a very great disruption process. The role of the teacher who has been the sole provider of knowledge has more or less shifted away from him/her. In the future, the role and presence of teachers in the classroom will

\footnotetext{
${ }^{7}$ MAXINE BERG and PAT HUDSON, "Rehabilitating the Industrial Revolution," The Economic History Review 45, no. 1 (1992): 24-50, https://doi.org/10.1111/j.14680289.1992.tb01290.x.
}

be increasingly challenging and require very high creativity. The era of the industrial revolution 4.0 is a formidable challenge for teachers. In the 2018 World Economic Forum annual meeting, stated globally that education is the biggest challenge of this century. If it does not change the way of teaching and learning, the next 30 years will experience great difficulties. Education and learning that are loaded with knowledge overriding the content of attitudes and skills as currently being implemented, will result in students who are unable to compete with machines. The dominance of knowledge in education and learning must be changed so that one day children in Indonesia are able to surpass machine intelligence while being able to be wise in using machines for benefit.

The era of the industrial revolution 4.0 will have an impact on the role of learning process, especially the role of teachers. ${ }^{9}$ If the role of teachers still retains as a conveyor of knowledge, then they will lose the role in line with technological developments and changes in learning methods. This condition must be overcome by increasing the competence of educators who support knowledge for exploration and creation through independent learning.

\section{Learning Framework in the Industrial Era 4.0}

\footnotetext{
8 Pat Hudson, The Industrial Revolution (Wales: Bloomsburry, 2014).

9 Pat Hudson.
} 


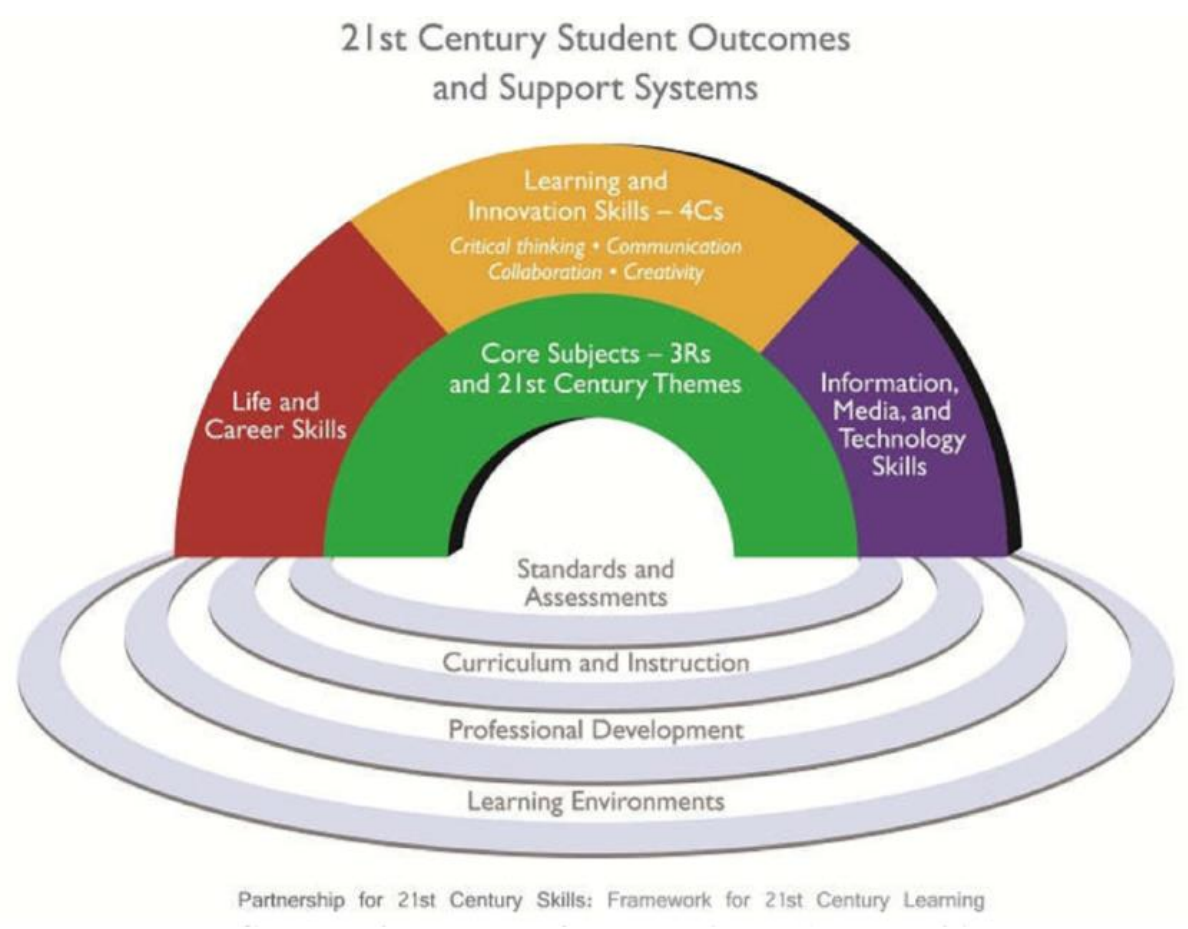

Figure 2. Eduction Framework Century 21

The 21st century is marked by the era of the industrial revolution 4.0 as a century of openness or a century of globalization, meaning that human life in the 21st century underwent very fundamental changes, which are different from the order of life in the previous century. ${ }^{10}$ It is said that the 21 st century is a century that asks for quality in all human endeavors and work. Naturally, the 21st century demands quality human resources, which are produced by institutions that are professionally managed so as to produce superior results. The all-new demands call for breakthroughs in thinking, drafting, and acting. In other words, a new paradigm is needed in facing new challenges. If these new challenges are faced using the old

10 B Trilling and C Fadel, 21st Century Skills.: Learning for Life in Our Times, 2009.

${ }^{11}$ Ester van Laar et al., "The Relation between 21st-Century Skills and Digital Skills: A Systematic paradigm, then all efforts will fail. The new challenge requires a breakthrough thinking process if what is desired is quality output that can compete with the work in a completely open world.

In the context of 21st century learning, learning in the classroom that applies creativity, critical thinking, collaboration, communication skills, community and character skills, must still be improved.11 Utilization of various learning activities that support the industry 4.0 era is a must. Like, resource sharing models with anyone and anywhere, as well as classroom and laboratory learning with virtual material, interactive, challenging, and meaningful learning that needs to be designed and realized in that era.

Literature Review," Computers in Human

Behavior 72 (July 1, 2017): 577-88, https://doi.org/10.1016/j.chb.2017.03.010. 
Unfortunately, this condition is still in contradiction with the implementation of the learning process currently happening. Learning is still limited by classroom walls that do not allow students to explore the real learning environment, namely family, community, and school. The teacher organizes the learning process always as usual and not how it should be, poor innovation and creation. The learning process at school is nothing more than a routine of repetition and delivery of information content of knowledge that does not hone students to develop creativity, taste, intention, and work and social care. Teachers organizing learning this year are still like previous years. $^{12}$

Partnership for 21st Century Learning develops learning frameworks in the 21st century that require students to have skills, knowledge and abilities in the fields of technology, media and information, learning and innovation skills as well as life and career skills. This framework also explains the skills, knowledge and expertise that must be mastered so that students can be successful in their lives and work. Consider figure 2.

According to Sukartono state that the 21st century learning paradigm emphasizes the ability of students to find out from various sources, formulate problems, think analytically and collaboratively and collaborate in solving problems. The explanation of the 21st

12 Keith Sawyer, The Creative Classroom: Innovative Teaching for 21st-Century Learners (London: Coloumbia University, 2019). century learning framework is as follows: (a) Critical-Thinking and Problem-Solving Skills, capable of thinking critically, laterally, and systemically, especially in the context of problem solving; (b) Communication and Collaboration Skills, able to communicate and collaborate effectively with various parties; (c) The ability to create and renew (Creativity and Innovation Skills), able to develop their creativity to produce innovative breakthroughs; (d) Information and Communications Technology Literacy, capable of utilizing information and communication technology to improve performance and daily activities; (e) Contextual Learning Skills (Contextual Learning Skills), able to undergo contextual independent learning activities as part of personal development, and ( $f$ ) Ability of information and media literacy, able to understand and use various communication media to convey various ideas and carry out collaborative activities and interaction with various parties. ${ }^{13}$

From the picture above can be explain that the 21st Century skills are (1) life and career skills, (2) learning and innovation skills, and (3) Information media and technology skills. The three skills are summarized in a scheme called "the 21st century knowledge-skills rainbow". The scheme was adapted by the non-profit organization P21, which developed a 21st century educational framework throughout the world through

\footnotetext{
${ }^{13}$ Sukartono Sukartono, "Revolusi Industri 4.0 Dan Dampaknya - Google Cendekia” (Surakarta, 2018).
} 
the website www.p21.org based in the state of Tucson, United States.

The schemes developed by 21st century learning are clarified with the addition of 3R core subject. In the context of education, 3R stands for reading, writing and arithmetic, a strong "R" pronunciation is taken of each word. From the subject of reading and writing, modern educational ideas emerge, namely literacy which is used as learning to understand ideas through words media. From the subject of arithmetic comes a modern education related to numbers which means that they can understand numbers through mathematics. In education, there is no single term that is relevant to literacy and numeracy that can express the ability to make something (wrighting). The 3R, adapted from the 18th and 19th centuries, is equivalent to the literacy, numeracy and ICT functional skills found in today's modern education system. Furthermore, to clarify the function of $3 \mathrm{R}$ core subject in the context of 21 st century skills, $3 \mathrm{R}$ is translated into life and career skills, learning and innovation skills, and information media and technology skills. ${ }^{14}$

The 21st Century skills that are considered able to strengthen social capital and intellectual capital, commonly abbreviated with 4C: communication, collaboration, critical thinking and problem solving, and creativity and innovation. Operationally, 4C is broken down into four step categories, namely: First, ways of thinking, including creating,

\footnotetext{
${ }^{14}$ Afandi et al., "Development Frameworks of the Indonesian Partnership 21 St -Century Skills Standards for Prospective Science Teachers: A
}

innovating, being critical, solving problems, making decisions, and proactive learning. Second, how to work, including communicating, collaborating, working in teams. Third, how to live as a global and local citizen at the same time; and fourth, tools for developing 21st century skills, namely information technology, digital networks, and literacy.

\section{Teacher Competencies in the industrial era 4.0}

The 4.0 Industrial Revolution which is full of super fast technology will bring significant changes, one of which is the learning process in Indonesia. Changes in the education system will certainly also have an impact on the role of teachers as educators. Teachers are required to have high competence to produce students who are able to answer the challenges of the Industrial Revolution 4.0. There are five competencies that teachers must prepare for entering the Industrial Revolution 4.0 era, namely, first, educational competence, internet-based learning competencies as basic skills; second, competence for technological commercialization. This means that a teacher must have competence that will bring students to have an entrepreneurial attitude with technology for the students' work of innovation; third, competence in globalization, that is, teachers do not stutter about various cultures and are able to solve educational problems. Fourth, competence in future strategies in the

Delphi Study," Jurnal Pendidikan IPA Indonesia 8, no. 1 (March 1, 2019): 89-100, https://doi.org/10.15294/jpii.v8i1.11647. 
sense of competence to predict precisely what will happen in the future and its strategy, by means of joint, joint-research, joint-resources, staff mobility, and rotation. Fifth, counselor competence, namely the competence of teachers to understand that in the future the problem of students is not only difficult to understand teaching material, but also related to psychological problems due to the times. ${ }^{15}$

\section{Research Method}

As Mestika Zed state that the research methodology used in this paper is the library research methodology. Almost all types of research require literature study. The difference between library research and field research, both of which still require library research. The main difference is in the purpose, function, and / or position of the literature study in each of the studies. In field research, library research is primarily intended as an initial step to prepare a research framework and / or proposal to obtain similar research information, deepen theoretical studies, or sharpen methodologies. Meanwhile, in library research library search is more than merely serving the functions mentioned above. Library research as well as utilizing library resources to obtain research data. Strictly speaking library research limits its activities to library collection materials without the need for field research

The main characteristics of library studies are: a) researchers deal directly

\footnotetext{
15 Daryanto and Syaiful Karim, Pembelajaran Abad 21 (Yogyakarta: Gava Media, 2017).
}

with text or numerical data and not with direct knowledge from the field or eyewitnesses in the form of events, people, or other objects, b) library data is "ready use "(ready made), meaning that researchers do not go anywhere, except only dealing directly with source material that is already available in the library. Like learning to ride a bicycle, people don't need to read books or articles about how to ride a bicycle. Likewise with library research, to do library research, one does not need to master library science. The only way to use the library appropriately is to directly use it, c) library data is generally secondary sources, in the sense that researchers obtain material from the second hand and not original data from the first hand in the field, d) The condition of library data is not limited by space and time. Researchers are dealing with static data, still. This means that whenever the researcher comes and goes, the data will never change because it is already "dead" data stored in a written record (text, numbers, pictures, tape or film). ${ }^{16}$

\section{Corroboration Method}

The method used in this research is the corroboration method. corroboration can be interpreted literally as "corroboration evidence", is a major part of the research method to support or strengthen the truth of a fact by comparing or contradicting two or more facts from various sources to solve the problem. In this case the credibility of a source needs to be corroborated, that is to confirm it

\footnotetext{
16 Mestika Zed, Metode Penelitian Kepustakaan (Jakarta: Pustaka Obor Indonesia, 2004), 1-5.
} 
with the available facts. Corruption is often a test that determines the truth of a statement after passing through internal criticism. In a sense corroboration is similar to the concept of "triangulation" in qualitative methods. ${ }^{17}$

\section{Results and Discussion}

From the study of the theory above, the researchers found, first, that currently humans live in the era of industry 4.0 or the era of disruptive where there is a very large and fundamental change in human civilization as a result of advances in digital technology or Information and Communication Technology. This change in civilization will directly affect changes in learning processes that are adaptive to these developments in preparing generations for life in the future

The second finding is that skills need to be formulated that students must have in this industry 4.0 era. The skills can be presented in the following table:

Table: The 21st Century Learning Framework

\begin{tabular}{|c|c|}
\hline \multicolumn{2}{|c|}{ Core Subject } \\
\hline \multicolumn{2}{|c|}{ Reading, wRiting, aRithmetic (3R) } \\
\hline $\begin{array}{c}\text { Strengten } \\
\text { Intellectual Capital }\end{array}$ & Strengten Social Capital \\
\hline $\begin{array}{l}\text { Critical-Thinking and } \\
\text { Problem-Solving } \\
\text { Skills } \\
\text { Creativity and } \\
\text { Innovation Skills }\end{array}$ & $\begin{array}{l}\text { Communication skills } \\
\text { Collaboration Skills }\end{array}$ \\
\hline \multicolumn{2}{|c|}{ How to do or work } \\
\hline $\begin{array}{l}\text { Information lite } \\
\text { Information and } C\end{array}$ & $\begin{array}{l}\text { acy, Media literacy, } \\
\text { mmunication literacy }\end{array}$ \\
\hline
\end{tabular}

From the table above it can be explained that the core subjects that need to be strengthened are reading, writing, and arithmetic or often known as 3R. The skills that students need to build and possess are Critical-Thinking and Problem-Solving Skills, Creativity and Innovation Skills, Communication skills, and Collaboration Skills and are often known as 4C. Meanwhile, how students work needs to be equipped with Information literacy, Media literacy, Information and Communication literacy.

The final finding in this study is trying to uncover what competencies teachers need to have in order to be able to teach adaptively in accordance with the demands of the industrial revolution era 4.0. From the reference study it can be concluded that the competencies that the teacher needs to have are as follows: a) educational competence, internet-based learning competencies as basic skills, b) competence for technological commercialization, teacher must have competence that will bring students to have an entrepreneurial attitude with technology for the students' work of innovation, c) competence in globalization, teachers don't stutter about various cultures and are able to solve educational problems, d) competence in future strategies in the sense of competence to predict precisely what will happen in the future and its strategy, and e) counselor competence, teachers to understand that in the future the problem of students is not only difficult to understand teaching material, but also related to psychological problems.

\footnotetext{
17 Zed, 88.
} 


\section{Conclussion}

From this study above, it can be concluded briefly that teachers need to realize that, now and in the future, the structure of human civilization has and is changing fundamentally, massively, and rapidly as a result of the development of digital and internet technology. Classroom learning should harmonize with these developments so that one day students can be able to compete and be wise towards intellent artificial. So that teachers can make changes in the world of teaching, teachers are required to have competence in the era of industry 4.0 such as mastery of the internet and so on.

\section{REFERENCES}

Afandi, Sajidan, M. Akhyar, and N. Suryani. "Development Frameworks of the Indonesian Partnership 21 St Century Skills Standards for Prospective Science Teachers: A Delphi Study." Jurnal Pendidikan IPA Indonesia 8, no. 1 (March 1, 2019): 89-100. https://doi.org/10.15294/jpii.v8i1.1 1647.

Afrianto, Afrianto. “Being a Professional Teacher in the Era of Industrial Revolution 4.0: Opportunities, Challenges and Strategies for Innovative Classroom Practices." English Language Teaching and Research 2, no. 1 (December 22, 2018). http://ejournal.unp.ac.id/index.php/ eltar/article/view/102675.

BERG, MAXINE, and PAT HUDSON. "Rehabilitating the Industrial Revolution." The Economic History Review 45, no. 1 (1992): 24-50. https://doi.org/10.1111/j.1468-

0289.1992.tb01290.x.

Daryanto, and Syaiful Karim.

Pembelajaran Abad 21. Yogyakarta:

Gava Media, 2017.

Goldstone, JA. "Efflorescences and

Economic Growth in World History:

Rethinking the" Rise of the West" and the Industrial Revolution." Journal of World History 3, no. 2 (2002): 323389.

Guzmán, Valeria E., Bernd Muschard, Mateus Gerolamo, Holger Kohl, and Henrique Rozenfeld. "Characteristics and Skills of Leadership in the Context of Industry 4.0." In Procedia Manufacturing, 43:543-50. Elsevier B.V., 2020.

https://doi.org/10.1016/j.promfg.20 20.02.167.

Johnstone, A. H. "The Development of Chemistry Teaching: A Changing Response to Changing Demand." Journal of Chemical Education 70, no. 9 (1993): 701-5. https://doi.org/10.1021/ed070p701

Laar, Ester van, Alexander J.A.M. van Deursen, Jan A.G.M. van Dijk, and Jos de Haan. "The Relation between 21st-Century Skills and Digital Skills: A Systematic Literature Review." Computers in Human Behavior 72 (July 1, 2017): 577-88. https://doi.org/10.1016/j.chb.2017. 03.010.

Pat Hudson. The Industrial Revolution. Wales: Bloomsburry, 2014.

Savitri, A. Revolusi Industri 4.0: Mengubah Tantangan Menjadi Peluang Di Era Disrupsi 4.0. Yogyakarta: Genesis, 
2019.

Sawyer, Keith. The Creative Classroom:

Innovative Teaching for 21st-Century

Learners. London: Coloumbia

University, 2019.

Sreberny, A, and A Mohammadi. Small

Media, Big Revolution:

Communication, Culture, and the

Iranian Revolution. Minnesota:

University of Minnesota, 1994.

Sukartono, Sukartono. "Revolusi Industri 4.0 Dan Dampaknya - Google

Cendekia." Surakarta, 2018.

Trilling, B, and C Fadel. 21st Century

Skills.: Learning for Life in Our Times, 2009.

Zed, Mestika. Metode Penelitian

Kepustakaan. Jakarta: Pustaka Obor Indonesia, 2004. 
168 | ibriez | Junal Kependidikan Dasar $\mid$ Vol 5 No 2 Tahun 2020 